\title{
Histórias do salto com vara no Brasil: entrevistando Sinibaldo Gerbasi
}

\author{
Fernando Paulo Rosa de Freitas* \\ Sara Quenzer Matthiesen**
}

\section{Introdução}

São muitas as dificuldades encontradas quando se objetiva percorrer a história do atletismo no Brasil. Algumas delas são facilmente constatáveis, como é o caso da pequena quantidade de livros que tratam do assunto, da dispersão ou conflito de informações existentes ou dos raros registros sobre competições e atletas, especialmente quando se trata de algumas provas, como é o caso do salto com vara.

Para se ter uma ideia, em sites nacionais, inclusive os da Confederação Brasileira de Atletismo (CBAt) e suas federações, essa história está restrita a alguns poucos nomes de atletas e resultados. Curiosamente, foi em sites estrangeiros que encontramos menções a atletas brasileiros pouco conhecidos no próprio país. Foi o caso de Walter Rehder, o primeiro brasileiro a ganhar a prova do salto com vara em um campeonato sul-americano (1937); Lúcio de Castro, atleta brasileiro que competiu nos X Jogos Olímpicos de 1932; Ícaro de Castro, representante do Brasil na prova do salto com vara nos XI Jogos Olímpicos de Berlim em 1936 e, finalmente, Sinibaldo Gerbasi, medalha de bronze na primeira edição dos Jogos Pan-Americanos, disputados em Buenos Aires, no ano de 1951 (GBrAthletics, [s.d.]).

* Membro do Grupo de Estudos Pedagógicos e Pesquisa em Atletismo (Geppa) - Universidade Estadual Paulista (Unesp), Campus de Rio Claro.

** Coordenadora do Grupo de Estudos Pedagógicos e Pesquisa em Atletismo (Geppa) - Universidade Estadual Paulista (Unesp), Campus de Rio Claro. 
Tal constatação nos motivou a intensificar as pesquisas desenvolvidas pelo Grupo de Estudos Pedagógicos e Pesquisa em Atletismo (Geppa), da Universidade Estadual Paulista (Unesp), Campus de Rio Claro, que, nos últimos tempos, tem se dedicado ao estudo da história das provas do atletismo, visando sua aplicação em aulas de educação física no campo escolar. Não à toa, nos detivemos ao estudo da prova do salto com vara, a fim de descobrirmos o paradeiro de um dos representantes brasileiros mais ilustres da época em que ainda se utilizavam implementos de bambu: Sinibaldo Gerbasi.

Nascido em 6 de junho de 1921 em São Paulo, onde vive atualmente cercado por lembranças e belas imagens de sua participação esportiva, Sinibaldo Gerbasi foi pouco a pouco revelando, por meio dessa entrevista, preciosidades acerca da história da prova do salto com vara.

Ex-atleta dessa prova, representante e medalhista do Brasil em competições importantes como os Jogos Sul-Americanos e Pan-Americanos, esse brasileiro, de família italiana, competiu entre as décadas de 1940 e 1950.

Ao nos encontrarmos no dia 23 de maio de 2008 com quem talvez seja o último remanescente dessa época, já próximo aos seus 87 anos de vida, nos deparamos com uma história repleta de aventura e pioneirismo, desvendada na entrevista que transcrevemos a seguir.

Fernando Paulo Rosa de Freitas - Seu Sinibaldo, o senhor poderia contar alguma coisa sobre suas origens, o lugar onde o senhor nasceu?

Sinibaldo Gerbasi - Nasci aqui nas Perdizes [bairro da cidade de São Paulo], onde é o Pão de Açúcar hoje. Fui o primeiro aqui. Inaugurei o registro do cartório. Folha 1, número 1. Estou com 87 anos!

FPRF - E a família do senhor, era daqui também?

SG - Não. Meu pai era italiano. A família dele veio visitar o Brasil. Vieram para passar um mês, acabaram ficando três meses. Meu pai tinha uns 14 ou 15 anos, mais ou menos, e se encantou com o Brasil. [...] Acabou voltando para cá quando tinha uns 20 anos. Trouxe representações que ainda não tinha muito por aqui. Tinha muito italiano, e não tinha vinho, era só comida [...].

FPRF - E como foi a sua infância aqui em São Paulo? 
SG - Bem, normal! A minha mãe era uma ótima pessoa, mas não entendia nada para ter um filho. Então, ela tinha um exagero comigo. Qualquer coisa ela me levava ao médico. Já usava óculos... então eu ficava meio nervoso. Até que um médico se cansou [risos], e disse: "Olha aqui minha senhora, a senhora precisa soltar esse menino em um campo, ele tem energia demais." Aí, com uns 4 ou 5 anos, meu pai me levou para o Clube Pinheiros. Foi a minha salvação!

FPRF - Para o Clube Pinheiros?

SG - Na época se chamava Germânia, era só de alemães. Foi o Pinheiros que me salvou. Larguei dos meus óculos, comecei a me desenvolver. Meu pai dizia que eu era meio raquítico. O clube foi minha segunda casa!

FPRF - E da escola, seu Sinibaldo, o senhor lembra se fazia educação física?

SG - Fazia-se uma educação física muito vagabunda, vestido mesmo. Era mais o futebol.

FPRF - Já naquela época era assim? Era mais o futebol mesmo?

SG - Já naquela época era o futebol.

FPRF - Era uma escola particular?

SG - Era escola particular. Depois eu fui para o Rio Branco, também um ótimo colégio, e, depois, para a Escola de Direito, mas não me formei. Eu preferi ser marido a ser doutor.

FPRF - Uma boa escolha, não é?

SG - Apaixonei-me pela Alzira [pegando o porta-retratos com a foto de D. Alzira, junto a um grupo de familiares e amigos]. Olha aqui a foto dela. Apaixonei-me e larguei da escola para casar.

FPRF - E naquela outra foto ali [apontando para a foto de um atleta em pose de halterofilista], é o senhor? 
$S G-E$.

FPRF - O senhor estava em boa forma. Naquela época, o pessoal que fazia salto com vara também treinava com pesos?

SG - Tinha poucos no Clube Pinheiros. O rio passava por dentro do clube, então, eu me dedicava mais às meninas de lá do que ao esporte [risos].

FPRF - O senhor teve a oportunidade de praticar outros esportes nesse clube?

SG - Não, ali eu fiz pouca coisa de outros esportes. Lá, eu fiz mais o atletismo. Todo grande saltador de vara daqui, pode-se dizer, saiu do Pinheiros: o Lúcio de Castro, que foi mais ou menos quem me ensinou... teve o Ícaro, teve o Walter Rehder, que era o "Alemão"...

FPRF - Por falar em Walter Rehder, deixe-me lhe fazer uma pergunta: o senhor conheceu o Walter Rehder?

SG - Conheci.

FPRF - O irmão dele chamava-se João Rehder Neto. O João Rehder Neto foi decatleta. Estou até meio emocionado de falar dele, porque o senhor conheceu uma pessoa que é lá de minha cidade, Rio Claro. O senhor conheceu, e muita gente da minha cidade não conhece! $!^{1}$

SG - Ele foi um bom atleta, saltou 4 metros [no salto com vara].

FPRF - Parece que ele foi o primeiro brasileiro a se tornar campeão sul-americano do salto com vara.

SG - Uhnn... sabe que eu não me lembro?

1 Os irmãos João Rehder Neto e Walter Rehder foram campeões sul-americanos das provas do decatlo e do salto com vara, respectivamente, no ano de 1937 (GBrAthletics, [s.d.]; Valdanha Neto, 2006). 
FPRF - Eu até marquei a data, foi em 1937. Depois o senhor competiu, acho que uns anos depois dele, não foi? Só que eu não sei se ele ainda é vivo. $\mathrm{O}$ irmão dele eu sei que faleceu, o João Rehder Neto.

SG - Eu acho que não deve ser vivo não, porque... de vivo acho que só tenho eu [risos].

FPRF - E o senhor não sabe a alegria que eu tive de lhe encontrar, sabe? Porque eu procurei também pelo Lúcio de Castro...

SG - Encontrou o Lúcio?

FPRF - Encontrei alguma coisa sobre ele pesquisando na internet. Encontrei uma corrida de rua em Guaratinguetá em que fizeram uma homenagem para ele. Eu pedi informações aos organizadores, e eles me mandaram umas fotos dele, quando estava já com a idade bem avançada. Ele faleceu faz uns dois ou três anos. Disseram que ele estava bem até o final da vida, e que estava morando em um abrigo para idosos $[\ldots]$.

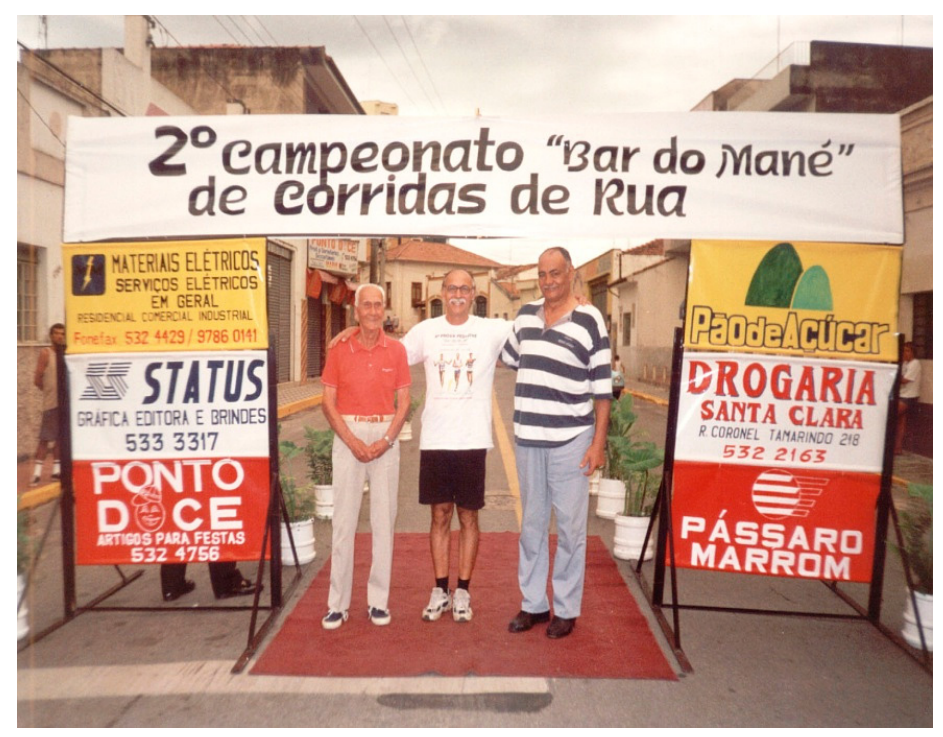

Figura 1. Lúcio de Castro (à esquerda), sendo homenageado em 2001, durante corrida pedestre em Guaratinguetá (SP) (Acervo pessoal de M. Laura). 
SG - O Lúcio foi muito meu amigo. Eu fui para Bauru e levei-o comigo [...]. Lá era só futebol. Eu pegava a rapaziada que estava nos bares de lá e levava para o atletismo.

FPRF - Então, já naquele tempo, o atletismo já era deixado de lado nos clubes?

SG - Ficava meio de lado. Agora, no Pinheiros era fantástico! No tempo dos alemães nós fazíamos muito esporte. Naquela época era bom, não era esse negócio de roubar atleta de um clube para o outro, como é hoje no futebol, onde quem tem mais dinheiro faz o melhor clube. Naquela época, os atletas eram todos feitos dentro do clube e não saíam. Tinha no Pinheiros, tinha no Paulistano... Tietê tinha atletismo... o Espéria. $\mathrm{O}$ atleta se fazia no clube e não se mudava. Então, os atletas eram do próprio clube, não tinha esse negócio de roubar atleta um do outro não!

FPRF - Quando o senhor começou a treinar lá no Pinheiros, quem foi seu primeiro técnico?

SG - Fritz Fust. Mas sabia pouco do salto com vara. O Lúcio, que se dedicou a vida toda ao atletismo, foi quem mais ou menos me ensinou.

FPRF - Tem uma passagem que eu fiquei sabendo sobre o Lúcio, durante os Jogos Olímpicos de 1932, em que o melhor resultado brasileiro foi o $6^{\circ}$ lugar dele, acho que foi em...

SG - Foi em Los Angeles...

FPRF - Isso. E o senhor, quais foram as principais competições que participou e seus melhores resultados? Pelo que eu tinha me informado, parece que foi nos I Jogos Pan-Americanos.

SG - É, 1951.

FPRF - E foi medalhista lá, não foi?

SG - Peguei $3^{\circ}$ lugar. Peguei $3^{\circ}$ e devia ter pego o $2^{\circ}$. Aliás, eu tive durante cinco anos o melhor resultado da América do Sul. O resto da América do 
Sul não saltava vara, era mais o Brasil. Mas mesmo assim, eu nunca consegui ganhar um sul-americano, peguei sempre em $3^{\circ}$ lugar. Eu sempre chegava saltando 4 metros e o jornal dava no dia seguinte: candidato certo à vitória, mas... Naquela época, a gente ficava um mês na competição, levávamos 25 dias, 20 dias...
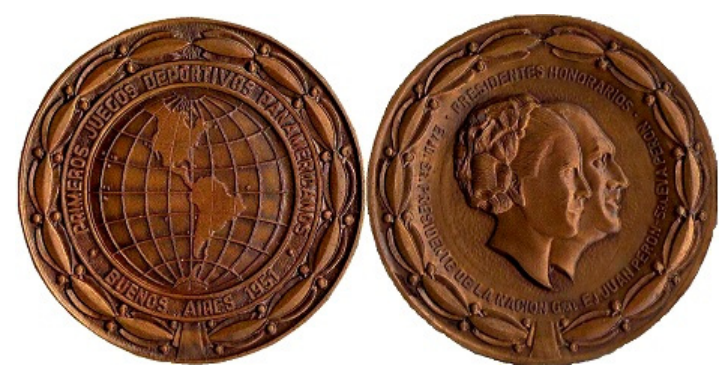

Figura 2. Frente e verso da medalha de bronze conquistada por Sinibaldo Gerbasi nos I Jogos Pan-Americanos, realizados em Buenos Aires, em 1951 (Acervo Pessoal Fernando Paulo Rosa de Freitas).

FPRF - Eram difíceis as viagens?

SG - Aí você tocou em um negócio interessante! Quando nós fomos para o Peru, quem foi dirigindo o avião militar nunca tinha atravessado os Andes. Então, nós notávamos que, de vez em quando, o avião vibrava, porque dava o que podia para conseguir passar por cima das montanhas. De repente, dava umas quedas no avião... vácuo, caía 20, 30 metros e todo mundo passava mal. Chegamos em Lima, depois de termos passado em diversas cidades. Acho que levamos 18 horas para chegar lá, foi um negócio medonho! Quando chegamos e saímos do avião, todo mundo sentou no chão passando mal. Foi uma coisa horrível!

FPRF - Os atletas de hoje em dia, pelo que a gente vê, não são todos que levam uma vida fácil, mas, em comparação com antigamente, eles têm algumas facilidades como, por exemplo, na hora de escolher a vara. Tem uma vara que é feita de acordo com o peso, com a velocidade que ele tem. Como é que eram os implementos, as varas na época em que o senhor competia? 
SG - Bambu [risos]. No Pan-Americano, eu apareci com minha varinha de bambu lá, e o Bob Richards, ${ }^{2}$ que era campeão do mundo naquela época...

FPRF - O senhor conheceu Bob Richards?

SG - [...] Eu tinha uma fotografia junto com ele, mas nem sei onde foi parar [...]. Então, eu perguntei para o Richards, ele falava em espanhol... enchi o peito e disse: "Eu sou campeão brasileiro. Queria que você me contasse como é o teu treinamento, o que você faz, tal..." E eu achava que, como ele era americano, devia ter 2 metros de altura!

FPRF - Ele não era muito alto?

SG - Não. Ele era mais baixo do que eu. [...] Olhei bem e vi que tinha mais braço que ele, que era mais alto do que ele. Ele saltava $4 \mathrm{~m} 40 \ldots 4 \mathrm{~m} 50$ ele saltou lá, parece. Eu era valente, era campeão brasileiro e tal. E disse: "Queria que você me falasse o teu treinamento." Olha, ele tinha cinco homens que trabalhavam com ele. Um que fotografava, um cinesiologista que olhava o movimento, tinha um que cuidava da alimentação. [...] Então eu falei com o Bob Richards: "O que você acha do meu estilo?", e ele disse: “Tu tiene gana, pero es mui malo." [risos]. Bom, mas eu não tenho estilo? "Não, o senhor não tem estilo nenhum." É, saltava assim, na força, vinha que nem um touro bravo para cima da vara e ia de qualquer jeito. Aí ele me falou: "Você pode ter um defeito!" E olha que eu saltei anos e anos, e com um defeito que só ele me contou. Nunca ninguém me falou nada, se estava errado. Vamos ver se você descobre aqui, Fernando [mostrando uma foto em que aparece saltando, no momento de passar sobre a barra e pouco antes de soltar a vara]. Professor, veja aí se você encontra o defeito!

FPRF - O braço direito flexionado? É isso ou a passagem sobre a barra? [tentando achar um possível erro técnico].

2 Robert "Bob" Richards iniciou sua participação olímpica na prova do salto com vara em 1948, conquistando o bronze. Posteriormente, se tornou bicampeão olímpico da prova, vencendo as edições de 1952 e 1956. Também venceu a prova nos I Jogos Pan-Americanos de 1951 (GBrAthletics, [s.d.]). 


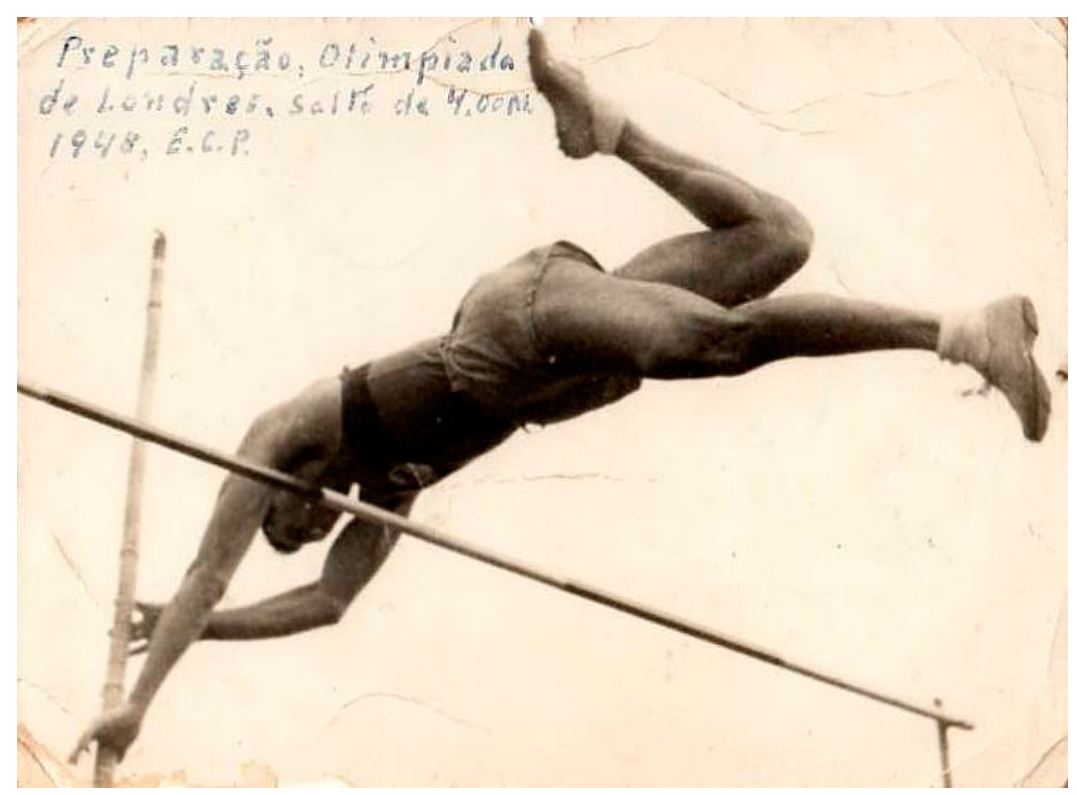

Figura 3. Sinibaldo Gerbasi treinando para os XIV Jogos Olímpicos de Londres, em 1948, antes de saber de seu "corte" (Acervo pessoal de Sinibaldo Gerbasi).

SG - Veja, olha aqui, este é meu braço direito? Olha aqui, meu braço direito, está vendo do outro lado dentro da mão? Olha a esquerda, onde está segurando. Eu sempre pegava a vara assim! Eu jogava a vara, ficava com este braço esquerdo para baixo. O primeiro, o mais alto era o direito. Eu tinha que empurrar com o direito e eu empurrava com o esquerdo. Não empurrava com o direito. Então, ele falou: "Você está perdendo 30 centímetros no teu salto. Fazendo um pouco de treinamento, você vai aumentar 30 centímetros, só que tem que empurrar com a direita." Com o direito dava uns 30 centímetros mesmo.

FPRF - E esse encontro com o Bob Richards, onde é que aconteceu?

SG - Na Argentina. Era um otimismo que tinha na Argentina no PanAmericano. Eu ganhei essa medalha da Evita Perón, ela mesmo entregando. Olha se tem cabimento... Eram os dois ali [referindo-se a Evita e Juan Perón]. Mas sabe que eu nunca liguei muito para isso! Porque eu peguei com tanta 
facilidade o salto com vara, que eu não dava muito valor pra ser campeão brasileiro, nem sul-americano. O que eu queria ser era um atleta olímpico. Então, quando foi em 1948 - tenho até o passaporte na gaveta -, eu fui escalado para a Olimpíada... Sabe que eu, nessa Olimpíada, já estava com o passaporte [pegando e mostrando o passaporte que estava em uma gaveta] marcado para Londres. Então, faltavam uns quatro dias para o embarque, e eu treinei muito, estava bem, e estava num entusiasmo danado, porque eu sempre achei que atleta mesmo é o que foi para uma Olimpíada. Atleta do salto com vara, onde ninguém salta de vara direito... Eu digo, uma Olimpíada é onde consagra o atleta, né? Eu já tinha arranjado uns dólares para levar. Faltavam uns dois dias para o embarque e veio uma notícia: "Cortaram quatro atletas por falta de verba." Aquilo lá para mim foi como jogar um balde de água gelada em cima de mim. [...] Não vai, não vai e acabou. Não se discute!

FPRF - Foi um golpe!

SG - Ah, mas eu senti demais aquilo, de não ter ido para a Olimpíada. Eu queria era ser um atleta olímpico. Basta ir para uma Olimpíada. O $6^{\circ}$ lugar saltou $3 \mathrm{~m} 90$. Eu ia disputar o $6^{\circ}$ lugar. Aquilo lá foi para mim... parei de treinar! Parei uma porção de tempo de treinar, depois voltei a treinar e continuei competindo.

FPRF - Naquela época, havia preconceito em relação àqueles que treinavam com pesos? E o salto com vara, o pessoal gostava de fazer muita brincadeira?

SG - Não, quanto ao preconceito propriamente... a gente achava que o pessoal que levantava pesos era Tarzan de praia! Que a musculatura deles só servia para tirar fotografia. Agora eu fiz bastante halteres também, mas porque eu achava que precisava. $\mathrm{O}$ erro aqui é que, quando você chegava num clube e queria ser saltador de vara, o técnico pegava você e: “Tá aqui a vara, vamos lá, vamos experimentar.” Então você tinha distensão, acabava com a carreira do atleta. Você tem que fazer uma boa preparação. Os bons atletas de salto com vara, vão buscar nos ginásios. Tem que fazer um ano mais ou menos de ginástica, para depois pegar a vara.

FPRF - Eu esqueci de perguntar, estávamos falando das varas daquele tempo que eram de bambu... 
SG - Ah, sim... Hoje não é mais fibra, não é? É carbono.

FPRF - Fibra de carbono, fibra de vidro. Agora eles estão misturando também, usando os dois, porque parece que a fibra de vidro dá uma...

SG - Enverga mais...

FPRF - Quando se usavam as varas de bambu, quem era o responsável por conseguir essas varas e como...

SG - Compravam-se as varas em casas de esporte. Parece que, aqui em São Paulo, uns japoneses é que preparavam as varas. Parece que passavam um pouco no calor, no fogo. Tinha um jeito de preparar a vara. A vara de bambu também dava um "galeiozinho" [simulando uma pequena flexão]. Por exemplo, para saltar 4 metros, você tinha que ter uma vara pesada. Quando eu fui competir com o padre, que ele não era padre, era pastor [Bob Richards], ele tinha uma vara de duralumínio.

FPRF - Já tinha começado a aparecer essas varas?

SG - Já. Quando ele chegou lá, ele tinha uma vara diferente, melhor do que a de todos aqui na América do Sul. Ninguém conhecia aquilo, e ele apareceu com uma vara de duralumínio. Saltou $4 \mathrm{~m} 50$, parece!

FPRF - Isso em Buenos Aires?

SG - Buenos Aires. Nós saltamos lá. Parece que quem ganhou o 2 lugar saltou $3 \mathrm{~m} 90$. Eu não sei se eu fiquei com $3 \mathrm{~m} 90 \mathrm{~m}$ ou $3 \mathrm{~m} 80$.

FPRF - As varas daquele tempo, elas vinham do Japão, ou...

SG - Não, comprava-se aqui, elas eram feitas aqui.

FPRF - O Japão também teve bons saltadores no começo do século passado, e parece que foram os primeiros a ter boas varas de bambu. Mas e para viajar com elas, dava para levar no avião ou se usava as que tinha nas competições? 
SG - Eu tinha um conversível! Meu pai ia segurando a vara no conversível. Aonde ia, se levava a vara. Fui para Bauru, levei a vara... No avião, a vara ficava no chão. Era como um músico... tinha que levar o instrumento junto.

FPRF - E para cuidar delas? Não podia deixar no sol, não podia...

SG - Precisava ter cuidado, porque não podia deixar cair. Teve um tempo que eu precisava saltar e segurar a vara, porque não tinha gente nem para segurar a vara [...], saltava e corria para segurar a vara, senão, podia rachar. Não tinha gente nem pra segurar a vara. Treinei sozinho muito tempo. Com o Lúcio, bom... acho que treinei com o Lúcio umas dez vezes. Naquela época, que tinha o Walter, o Ícaro, eu treinei um pouco com eles, depois, então, comecei a treinar sozinho, porque não tinha ninguém para treinar [...]. Quando eu fui para o Pan-Americano, eu fui mal, estava em Bauru, não tinha onde treinar.
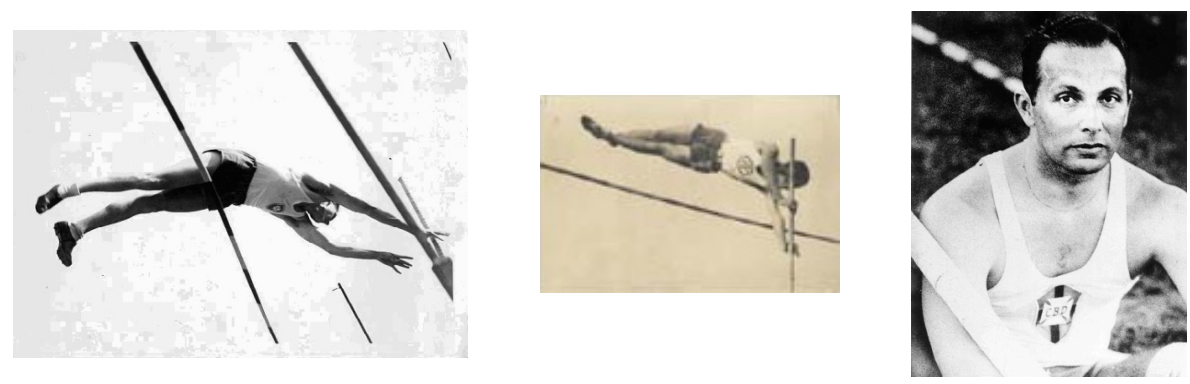

Figura 4, 5 e 6. Galeria de campeões do Esporte Clube Pinheiros. $\mathrm{Na}$ sequencia: Walter Rehder, Lúcio de Castro e ĺcaro de Castro Mello (Acervo do Centro Pró-Memória Hans Nobiling - Esporte Clube Pinheiros, acervo de fotos $n^{\circ} 3609,1345$ e 3265).

FPRF - Certo. O senhor teve algum reconhecimento da federação, da confederação, alguma coisa assim?

SG - Tive, do prefeito. Quando voltei do Pan-Americano, tinha uma cidadezinha perto de Bauru, acho que foi do japonês que pegou o $1^{\circ}$ lugar na 
natação, ${ }^{3}$ e fizeram uma homenagem ao rapaz. Então, o prefeito de Bauru da época [...] disse que também ia me fazer uma homenagem, me dar um brinde, não sei o que... Estou esperando até hoje! [risos].

FPRF - O pai do senhor te apoiava bastante, não é?

SG - O meu pai era demais! Com 18 anos tive uma motocicleta. Ele me deu uma Harley-Davidson. [...] Tirava o silencioso e, de madrugada, descia a Rebouças fazendo um barulhão, parecia um avião. Eu não sei como nunca me machuquei. Fiz uma porção de arte. Conheci um trapezista na Liberdade, e me encantei com o negócio de trapézio. Andei treinando no circo e consegui pôr o trapézio lá no clube, embaixo da plataforma de 10 metros. Eu balançava, virava no ar [...]. Eu tenho um calo ósseo, aqui [mostrando o pé], de quando eu caí de uma árvore. Eu tinha o sapato de prego e, no clube, tinha uns eucaliptos... eram lindos os eucaliptos! Um perto do outro uns $2 \mathrm{~m} 50$. Eu subia nos eucaliptos até os 3 ou 4 metros e pulava de um para o outro. [...] Eu empurrava o pé, virava no ar e pegava no outro eucalipto. Mas era o sapato de prego que fazia isso. Quem via, pensava: puxa! Me chamavam de gorila, [...] eu tinha muita agilidade, acho que nasci com essa agilidade. [...] Eu fiz mil e uma coisas... eu me arrisquei muito!

FPRF - Falando em se machucar, vemos que o salto com vara é um esporte... não vou dizer perigoso, mas que tem o seu risco, principalmente se quebrar a vara, se cair mal...

SG - [...] Por isso é que eu fui para o salto com vara. Gostava de correr riscos... de coisa mais difícil!

FPRF - E chegou a sofrer algum acidente treinando?

SG - Eu só me lembro uma vez. Isso já faz tanto tempo... Saltei 3m90 numa pista coberta, aqui no Pacaembu. ${ }^{4}$ Como foi uma competição internacional,

3 O nadador japonês a que Sinibaldo Gerbasi se refere é Tetsuo Okamoto, campeão dos Jogos Pan-Americanos de 1951, nos 400 e 1500 metros livres. Tetsuo era natural de Marília (SP).

4 Entre as medalhas de Sinibaldo Gerbasi, consta uma que traz a inscrição "Primeira competição em pista coberta do Brasil”. No verso, um desenho do estádio do Pacaembu. Sem saber precisar onde foi essa competição, imaginamos que essa cobertura da pista foi provisória ou realizada dentro de um ginásio. 
eles fizeram tudo de madeira, uma pista coberta onde eu saltei $3 \mathrm{~m} 90$. Eu quebrei a vara na hora do salto. Mas eu tinha bastante agilidade, me ajeitei e tal, e caí de pé... Teve um atleta que morreu no Tietê. Quebrou a vara, e ele caiu, bateu no toco, bateu no peito e ele morreu com o negócio. ${ }^{5}$

FPRF - Quem não conhece a história do salto com vara, quase não acredita que naquele tempo não havia o colchão para o atleta cair em cima.

SG - Que nada! Quando eu ia saltar, eu mesmo virava a areia para ficar mais mole um pouco, senão caía numa areia dura. E eu sofri um problema de rim por causa disso.

FPRF - Cair uma vez de 3m50, $4 \mathrm{~m}$ é uma coisa, mas, com o andar da competição, são várias quedas, não é? No final da competição como ficava o "físico"?

SG - Eu aguentava bem! O importante da vara é que você precisa jogar a vara direitinho, se não te dá um tranco aqui no ombro. Apesar que, quando eu saltava, não me preocupava muito com a queda. Primeiro era saltar o sarrafo, depois eu me ajeitava para cair. Uma vez só que eu caí, bati as costas... Foram falar comigo e não saía a voz.

FPRF - Bom, não sei se o senhor poderia falar mais de como eram os implementos naquela época, de como eram os treinos...

SG - As varas eram de bambu. E tinha uma coisa: não tinha técnico de vara no Brasil. Ninguém entendia de vara, nem nós, os atletas. O Lúcio saltou muito tempo e tinha o estilo dele, que ele chamava de "pêndulo". Ele fazia assim: [demonstrando] soltava, caía, e não fazia muita força com o braço porque ele não tinha muita musculatura. Mas ele saltou $4 \mathrm{~m} 12$, que foi o recorde sul-americano. Eu tinha prometido para mim mesmo que, se tivesse uma competição com ele, eu nunca iria ganhar dele, porque teve uma época que ele parou, ele não queria competir... e eu sempre vou respeitar o Lúcio [...]. Eu mesmo já tinha prometido: se tivesse que ganhar do Lúcio, do Lúcio não

5 Seu Sinibaldo não soube precisar exatamente como foi esse acidente, esclarecendo que não conheceu a vítima, mas que essa era uma história que se contava muito em sua época. Também não encontramos outras referências sobre esse fato. 
quero. Posso empatar com ele, mas ganhar nunca, porque eu estava mais em forma do que o Lúcio, e ele já estava mais no fim da carreira.

FPRF - Outra coisa: hoje em dia a gente escuta falar muito no uso de drogas, de "bomba". Naquele tempo já tinha isso?

SG - Tinha, tinha. Tinha o "Pervirtin"...

FPRF - Como é que se chama?

SG - Pervirtin. Era uma coisa que você levava na escola, e tomava para ficar acordado. Naquele tempo achavam que ficava mais inteligente com aquilo. Era um estimulante. Coisa que eu nunca tomei $[. .$.$] .$

FPRF - Seu Sinibaldo, da época que o senhor era atleta, lembra de mais algum caso interessante que gostaria de nos contar?

SG - Nós estivemos em Santa Cruz de la Sierra, onde aconteceu um monte de coisa. Tinha uma menina da delegação que saiu com uma calça vermelha, e era quinta-feira santa... foi presa. Prenderam e a levaram para a delegacia. Não podia usar vermelho na quinta-feira santa.

FPRF - Era um costume diferente e ninguém sabia?

SG - É. Eles estavam todos de preto na cidade. E foi um rebuliço, fomos todos para a delegacia para tirar a menina e explicar para o delegado que no Brasil não tínhamos esse costume.

FPRF - Bom, Seu Sinibaldo, eu agradeço!

SG - Eu não te dei nenhuma fotografia? Se você quiser levar esse negócio do Perón, leva, viu? [referindo-se à medalha do Pan-Americano] para você saber como era o peronismo lá na Argentina. Pode levar isso aqui também [uma foto em que estava saltando]. A fotografia está feia, "mal saltado", mas, se você quiser... isso aqui foi preparação olímpica, para saltar em 1948.

FPRF - Dá para ver bem a vara de bambu! Dá para ver bem o estilo da época! 
SG - Preparação para as Olimpíadas de 1948 [ajudando a tirar a foto do porta-retratos].

FPRF - Um salto de 4 metros... era uma boa queda, não é Seu Sinibaldo?

SG - É... Naquela areia era duro. [risos].

FPRF - [...] Novamente gostaria de agradecer e fazer uma última pergunta: o senhor tem saudades dessa época?

SG - Ah, foi a melhor época de minha vida. Era época que você fazia amizade, sem querer saber a conta bancária da pessoa, né? Era amizade sincera. $\mathrm{O}$ clube foi para mim minha segunda casa! Melhorei muito, e as amizades que eu fiz...

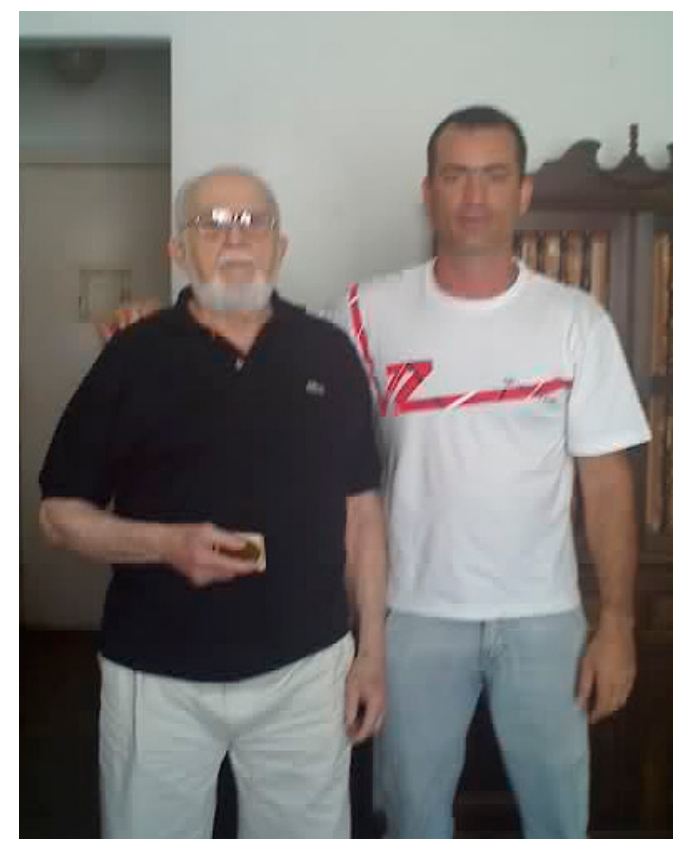

Figura 7. Sinibaldo Gerbasi e Fernando Paulo Rosa de Freitas, em 23 de maio de 2008 (Acervo pessoal de Fernando Paulo Rosa de Freitas). 
Ao término da entrevista, Sinibaldo Gerbasi insistiu em nos presentear com a medalha dos Jogos Pan-Americanos de 1951, dizendo que havia nos revelado coisas que jamais tinha dito a alguém.

Movidos pela emoção, pelo interesse mútuo de contar histórias e pelo amor comum aos esportes, a empatia entre entrevistador e entrevistado foi instantânea. Não havia como não simpatizar com um senhor que nos abrira as portas e nos recebera tão gentilmente, e como foi interessante ouvir suas histórias!

Ao final, constatamos que essa entrevista não serviu apenas para retomar fatos importantes da história do salto com vara no Brasil, mas, como observou Thompson (1998), serviu para nos certificarmos que as pessoas de mais idade também podem se beneficiar ao rememorarem sua própria vida, ao que o autor chama de terapia da reminiscência.

De nossa parte fica a alegria e o respeito por esse atleta brasileiro que dividiu conosco sua própria história, parte importante da história esportiva de nosso país.

\section{Referências}

GBRATHLETICS. South American Championship (Men). [s.d.]. Disponível em: <http:// www.gbrathletics.com/ic/sac.htm>. Acesso em: 26 nov. 2008.

THOMPSON, P. A voz do passado: história oral. 2. ed. São Paulo: Paz e Terra, 1998.

VALDANHA NETO, A. João Rehder Neto, o tigre brasileiro. Efdeportes.com, 2006. Disponível em: <http://www.efdeportes.com/efd96/rehder.htm>. Acesso em: 26 nov. 2008.

Resumo: A prova do salto com vara ganhou a atenção de todo o Brasil durante os Jogos PanAmericanos do Rio de Janeiro em 2007, quando dois atletas brasileiros - Fábio da Silva e Fabiana Murer - conquistaram as medalhas de ouro. Nas edições anteriores dessa competição, apenas outros dois atletas nacionais conquistaram medalhas de bronze: Thomas Hintnaus, nos Jogos de Caracas, em 1983, e Sinibaldo Gerbasi, na primeira edição dos Jogos Pan-Americanos, ocorrida em Buenos Aires, em 1951. Um dos pioneiros na representação do Brasil na prova do salto com vara, Sinibaldo Gerbasi rememora, nessa entrevista, passagens de sua vida como atleta; um registro importante para a história esportiva do país, e desconhecida pela maioria dos brasileiros.

Palavras-chave: salto com vara, história do esporte, atletismo. 


\title{
Histories of the pole vault in Brazil: interviewing Sinibaldo Gerbasi
}

\begin{abstract}
The pole vault proof got great attention throughout Brazil during the Pan American Games in Rio de Janeiro in 2007, when two Brazilian athletes - Fábio da Silva e Fabiana Murer - conquered golden medals. In this kind of competition previous editions, only two other national athletes won bronze medals: Thomas Hintnaus, at games in Caracas in 1983 and Sinibaldo Gerbasi, at the Pan American Games first edition, held in Buenos Aires in 1951. One of the pioneers in Brasil representation at the pole vault proof, Sinibaldo Gerbasi, remembers, during this interview, passages from his life as an athlete, an important registry for sporting history of the country, and unknown by most of the Brazilian people.
\end{abstract}

Keywords: pole vault, sport history, athletics.

Recebido em 02/07/2010

Aprovado em 15/09/2010 